\title{
American Youth Violence: Issues and Trends
}

\section{A B S T R A C T}

Census and arrest data suggest that all forms of violent youth crime increased more than the youth population during the 1960s. Since 1970 , however, per capita rates of youth homicide and rape have been stable as measured by arrest trends. Robbery by young offenders in 1977 was close to the per capita rate in 1970. Only the heterogeneous crime of aggravated assault has increased significantly through the 1970 s, and this increase may be a result of different patterns of police classification and reporting. Recent studies of youth crime have produced insufficient information on the concentration, predictability, and responsiveness to sanctions of youth violence. The data collected to date are far more ambiguous than has been acknowledged in the current debates about "cracking down" on youth violence or identifying and isolating "hard core" or career adolescent offenders.

In recent years, violent crimes committed by young offenders have become a focal point for public and political debate about crime and criminal justice policy. Of course, the problem is not in any sense novel or recent in origin. Presidential commissions and daily tabloids have long viewed serious crime by the young as a problem requiring attention and control (President's Commission on Law Enforcement and Administration of Justice 1967). But since the early 1970 s, the violent young offender has moved

Franklin E. Zimring is Professor of Law and Director, Center for Studies in Criminal Justice, University of Chicago Law School.

Fred Ackerson, a second-year student at the University of Chicago Law School, provided able and energetic research assistance in the preparation of this essay. Albert Reiss, Michael Tonry, Ted Gurr, Sheldon Messinger, and Norval Morris were kind enough to comment on an earlier draft.

67 
steadily up the list of public concerns about crime until it is fair to characterize youth violence as a central theme of the politics of crime control in 1979.

Evidence for this last assertion comes from the multiplicity of books (Boland and Wilson 1978; Strasburg 1978; Zimring 1978), media coverage, ${ }^{1}$ and legislative proposals ${ }^{2}$ that have emerged since the mid-seventies. The new notoriety of youth violence has already shifted discussions of juvenile justice reform from singleminded efforts to reduce overintervention in the lives of status offenders to acrimonious debate about appropriate responses to serious youth crime. The juvenile court's announced tradition of solicitous concern for its clientele is being tempered by the felt public need to deal with the predatory young. Thus, since 1976, New York's Family Court has had within its jurisdiction a category of "designated felons" for which extended terms of custodial confinement may be imposed upon adjudication of delinquency. ${ }^{3}$ The dissonant ring of the conjunction of such terms as "Family Court" and "designated felon" is neither superficial nor solely linguistic. Serious violence by young

'See, e.g., "The Youth Crime Plague," Time, 11 July 1977, pp. 18-30; "Beyond the Teen-Age Gun," New York Times, editorial, 28 June 1978, p. 30: American Broadcasting Company, "Youth Terror: The View from behind the Gun," television documentary presented 28 June 1978.

${ }^{2}$ A New York state law which took effect in September 1978 lowers the age of criminal responsibility to 13 years for first degree murder, kidnapping, arson, assault, manslaughter, rape, sodomy, and robbery; second degree murder, kidnapping, and arson; attempted murder, kidnapping, and arson. The age of criminal responsibility is 14 years for second degree robbery and assault when the juvenile has previously committed one of the enumerated felonies. When a juvenile has committed two prior felonies, he becomes criminally responsible for any felony committed after age 7 . The criminal responsibility accorded these "designated felony acts" is the penalty of "restrictive placement" of the juvenile, initially in a secure facility. The court may order restrictive placement after considering the background and best interests of the juvenile, the circumstances of the offense (including injuries inflicted), the need for community protection, and the age and physical condition of the victim. More severe penalties are provided for murder, kidnapping, arson, and repeated offenses; restrictive placement is mandatory for a designated felony offense in which the victim is 62 or more years of age and sustains "serious physical injury." N.Y. Jud. Law 88712,753 (a) (1978). Pennsylvania provides that juvenile felons 14 years and older may be transferred from the juvenile to the criminal courts if "the child is not amenable to treatment" through juvenile facilities and "the interests of the community require that the child be placed under legal restraint or discipline or that the offense is one which would carry a sentence of more than three years if committed by an adult." $11 \mathrm{~Pa}$. Cons. Stat. Ann. \$50-325 (1972) (Purdon).

${ }^{3}$ N.Y.S.L. 1976 , c. 878,83 (1976). 
offenders represents a substantial threat to the institutional credibility and to the mission of the contemporary Juvenile Court (Zimring 1978, chap. 5). Acts of violence committed by the young produce the worst conflicts between protecting young offenders and defending society that the legal system is likely to confront. Thus, the incidence and control of youth violence are important topics in their own right. Equally significant, the changing perceived importance of youth violence may have a broader impact on the treatment of young offenders in the legal system.

This essay reviews recent trends in youth violence as reported in police statistics and criminological studies of various youth populations. Section I discusses the uses and limits of official statistics on the four standard violent offenses collected by the Uniform Crime Reporting Program, and the utility of the violent offense index that is derived from adding these four offenses together. My reading of these official statistics suggests that the dramatic increase in youth violence during the 1960s has been followed in the 1970 s by a period of relative stability in the rate of three of the four violent offenses. The single exception to this moderating pattern-aggravated assault-shows large increases in the 1970s, but deaths from youth assault are stable. For that reason, it can be argued that changes in reporting practices may have influenced the statistics on assault and the entire violence index.

Section II discusses the supplementary methods used to measure youth violence. While much of this supplementary work is promising, police statistics are, and will remain, the primary source of information on the incidence and distribution of serious youth violence. Refinement and reform of official reporting is thus a necessity.

Section. III addresses the uses that are made of currently available data in relation to policy issues relating to social control of the violent young offender. Gaps in current knowledge are identified, and some suggestions for further research are put forward.

This essay is by no means a comprehensive treatment of youth 
violence. The following pages do not address current debate about the etiology of violent criminality or trends in the equally important and volatile area of youth corrections. In thus truncating what might be considered the "front" and "back" ends of a complex area of human behavior I yield important topics to other volumes and to other authors.

Two further preliminary considerations merit mention. This essay was solicited as a review of juvenile violence. In a survey of national patterns, the term "juvenile violence" may not be meaningless, but it certainly may be misleading. The maximum age for juvenile court jurisdiction varies among American states from an offender's sixteenth birthday in New York and Vermont to the nineteenth birthday in recent Wyoming legislation. ${ }^{4}$ More serious violent crimes are committed by individuals between these ages than by the total population under age sixteen. ${ }^{5}$ The variance and the arbitrariness of the legal boundary for juvenile court jurisdiction makes the concept of juvenile violence a singularly unhelpful criminological tool. To use an extreme example, reduction of the maximum age of juvenile court delinquency jurisdiction to the tenth birthday would abolish the problem of "juvenile violence" without any noticeable contribution to either criminological theory or social welfare. For that reason, this essay discusses the incidence of violent crime between ages 13 and 20, a period that encompasses the beginnings of violent careers in all but the most unusual cases and continues through to well beyond the typical maximum age of juvenile court involvement.

A second preliminary caution is necessary in relation to the types of violent acts that are the focus here. As Paul Strasburg has pointed out, dictionary definitions of violence are quite broad, typically including "rough or injurious physical force, action or treatment" (1978, p. 3). My focus is narrower, encompassing the four index offense categories thought by police and public to constitute violent crime-homicide, rape, aggravated assault, and

\footnotetext{
4 Wyoming Statutes $\$ 14-155,411$ (1976). For a national survey of jurisdictional age see Zimring 1978, pp. 45-46.

${ }^{B}$ In 1975 there were 68,928 arrests for violent crimes (murder, forcible rape, robbery, aggravated assault) of offenders aged 16-18 compared to 40,946 arrests of offenders under 16 (U.S. Dept. of Justice, FBI 1975, table 36).
} 
robbery. Within these offense categories, special emphasis will be accorded to acts of violence which generate substantial risks of death or serious bodily injury. The offenses surveyed do not exhaust the potential definition of violence. Vandalism, an offense which is almost the exclusive province of the young, often contains elements of threat or intimidation and is excluded from this discussion, just as it is excluded from most of the literature on youth violence under scrutiny. ${ }^{6}$ Traffic offenses, perhaps the single most lethal form of adolescent crime, are also excluded from the data upon which this review is based. ${ }^{7}$ The absence of youthful traffic "violence" from the public discussion of youth crime reflects a general tendency in American society to regard dangerous driving as normal and the risks associated with traffic as essentially noncriminal. Whether this omission reflects a public perception of the lack of intention to injure or American equanimity about the risks of driving, or both, is beyond the scope of this discussion.

But it is important to note that, in narrowing the emphasis of this essay to those offenses publicly perceived as most serious, the biases reflected in public perception will influence not only the behaviors selected for analysis but also some of the apparent conclusions one might draw about violent youth criminality. Crimes of prey, such as robbery, are concentrated in urban areas, and the offender population is disproportionately composed of minority males. Lethal (and criminal) traffic "violence" is more widely distributed across the youth population. ${ }^{8}$ An analysis which focuses on the former will show much more substantial urban, race, and class concentration than would result from a broader definition of violent criminality. As is true in the debate

- In 1975, 65 percent of the 175,865 reported vandalism arrests were of youths under $18 ; 38$ percent were of youths under 15 (U.S. Dept. of Justice, FBI 1975, table 36).

7 Of 55,511 motor vehicle accident deaths in $1973,9,309$ (17 percent) were fatalities in the 15-19-year age group (U.S. Dept. of Health, Education, and Welfare 1975, table 4-2).

- Measuring "traffic violence" by resulting fatalities, we find a race and geographic distribution similar to that of the national population. In 1973, 86 percent of auto accident fatalities were white and 58 percent occurred in non-urban areas (U.S. Dept. of Health, Education, and Welfare 1975, tables 4-2 and 7-9). 
between those who wish to focus on "street crime" and those who point out the harm and more substantial distribution of some white-collar crimes, there is no single focus of inquiry that is obviously preferable in analyzing behavior as heterogeneous as violations of the criminal law.

\section{Patterns and Trends in Youth Violence: Official Statistics}

However one chooses to measure, crime in the United States is predominantly the province of the young. Males between the ages of 13 and 20 comprise about 9 percent of the population but account for more than half of all property crime arrests and more than a third of all arrests for offenses typically regarded as involving violence. While such arrest statistics may be a biased sample of offenses, they are an important data set and deserve detailed consideration. Figure 1, using 1975 statistics, contrasts the age concentration of arrests for index property offenses

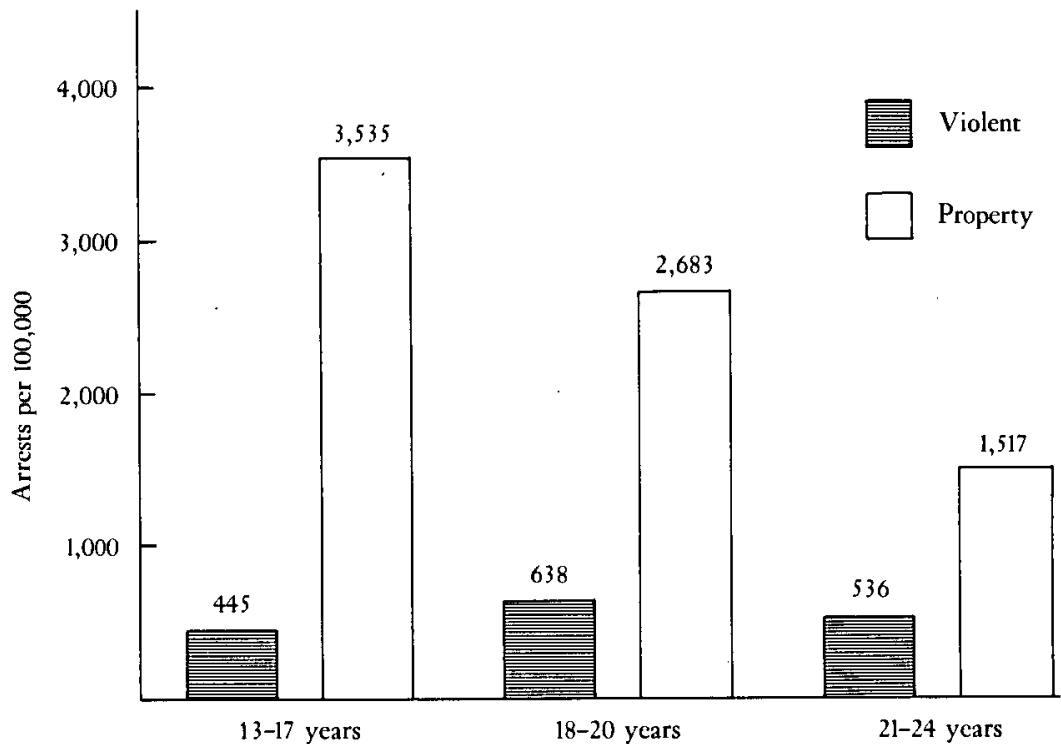

Fig. 1. Arrest rates by age for violent and property offenses, 1975. The violent offenses included are homicide, forcible rape, robbery, and aggravated assault. The property offenses are burglary, larceny-theft, and motor vehicle theft. Sources: U.S. Department of Justice, Federal Bureau of Investigation, Uniform Crime Reports, 1975 ; U.S. Department of Commerce, Bureau of the Census, Current Population Reports, Series P-25, No. 643 (January 1977). 
(burglary, larceny, auto theft) with arrests for violent crime. Property crimes are concentrated earlier in the adolescent years, while the aggregate category of crimes of violence peaks during ages 18-20. But this is too rough a comparison: a single category, "violent crime," is too heterogeneous for informed analysis. Public and legislative concern about violent crimes committed by young people tends to crystallize around well-publicized and unrepresentative episodes of violent crime committed by young offenders.

Any case that makes the front page of the Nerw York Times is almost certainly unrepresentative of the typical violent crime or violent offender. Homicide and rape are candidates for front-page treatment and public alarm, particularly where the offender is young and the victim is aged, vulnerable, or well known. ${ }^{9}$ Yet, 90 percent of all youth arrests for crimes classified by the FBI as violent are for robbery and aggravated assault. Robberies range from unarmed schoolyard extortions through armed, lifethreatening, predatory confrontations. Most robberies by young adolescent offenders tend to fall toward the less serious end of the scale, although precise statistics are not available. Similarly, aggravated assault as defined by the police varies from fistfights through shootings, carrying vastly different death risks and policy implications.

Figure 2 attempts to carry the analysis one step forward by separately considering the inevitably serious offenses of homicide and forcible rape and the more heterogeneous high-volume offenses of violence, using arrest statistics to reflect age-specific patterns of violent criminality. Arrests for homicide and rape are more frequent among 18-, 19-, and 20-year-olds than among the entire under-18 population, even though youths aged 13-17 constitute a substantially higher population at risk. The 1820-year age group also experiences higher rates of arrests for the "heterogeneous" offenses of robbery and aggravated assault, but the number of under-18 arrests for these offenses exceeds the

\footnotetext{
'See, e.g., "Boy, 15, Who Killed 2 and Tried to Kill a Third, is Given 5 Years," New York Times, 29 June 1978, p. 1; "Carey, in Shift, Backs Trial in Adult Court for Some Juveniles," New York Times, 30 June 1978, p. 1.
} 


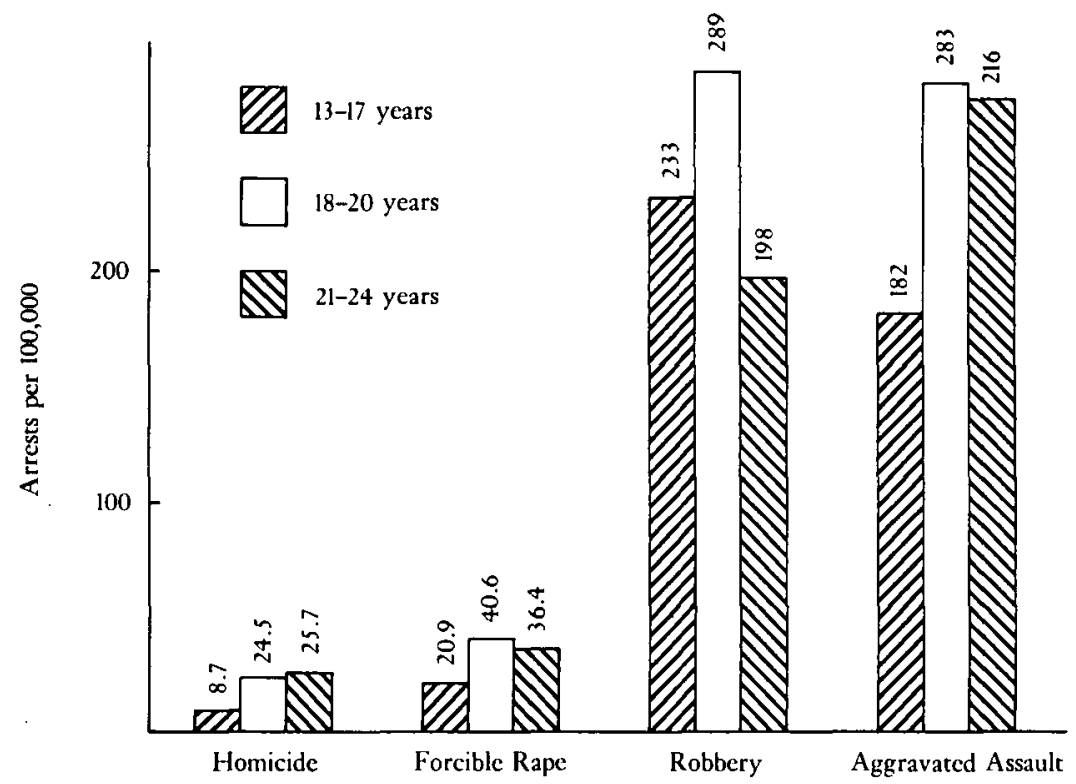

Fig. 2. Arrest rates by age for homicide, forcible rape, robbery, aggravated assault, 1975. Sources: U.S. Department of Justice, Federal Bureau of Investigation, Uniform Crime Reports, 1975: U.S. Department of Commerce, Bureau of the Census, Current Population Reports, Series P-25, No. 643 (January 1977).

absolute number of 18-20-year-old arrests; and the youth share of total arrests is thus more substantial. ${ }^{10}$

Two important conclusions can be drawn from these data. First, where the offense category is extremely serious, the number of under-18 arrests is small, at least in relative terms. Second, the bulk of adolescent arrests for crimes of violence, particularly in the under-18 category, are in the two classes of police-defined violence where the label of the arrest tells us relatively little about the degree of seriousness of the offense. For this reason, our ability to draw confident conclusions about the seriousness of youth violence over time or in comparing different areas on the basis of official statistics is quite limited as long as we deal with aggregated totals dominated by heterogeneous offenses (Strasburg 1978, pp. 4-5).

10 While 18-20-year-olds had a higher arrest rate, the under-18 population had more total arrests for robbery and aggravated assault in 1975. See Appendix, table A. 


\section{A. Homicide and Rape}

Table 1 examines arrest patterns for the two "homogeneous" serious offenses of violence over time for the period 1960 through 1977. While these official arrest statistics are hardly an ideal method of measuring youth violence, age-specific arrest statistics can serve as limited indicators in homogeneously serious offenses with relatively high clearance rates. With respect to homicide, youth arrest rates increased dramatically during the 1960s, leveled off from 1970 through 1975, and have since declined. If arrest rates are a reliable guide, persons under 21 were responsible for 18 percent of intentional homicide in 1960 and 25 percent of criminal homicide reported by the police in 1975. This is, however, an overestimate, because younger offenders are far more frequently arrested in groups and thus tend to have a higher arrest-to-crime ratio than other age categories. In Philadelphia, for example, we found that more than two offenders under 18 were

TABLE 1

Trends in Homicide and Forcible Rape Arrests for Offenders Aged 13-20, 1960-77

\begin{tabular}{|c|c|c|}
\hline & \multicolumn{2}{|c|}{$\begin{array}{c}\text { Estimated Arrests per } 100,000 \\
\text { Forcible }\end{array}$} \\
\hline & Homicide* & Rape \\
\hline 1960 & 7.6 & $24.0^{\circ}$ \\
\hline 1970 & 14.0 & 28.0 \\
\hline Change $(1960-70)$ & $84 \%$ & $17 \%$ \\
\hline $1975^{\circ}$ & 14.6 & 28.3 \\
\hline Change (1970-75) & $4 \%$ & $1 \%$ \\
\hline 1977 & 13.4 & 28.3 \\
\hline Change $(1975-77)$ & $-8 \%$ & $\ldots$ \\
\hline
\end{tabular}

* Homicide here includes murder and non-negligent manslaughter.

Sources: U.S. Department of Justice, Federal Bureau of Investigation, Uniform Crime Reports, 1960, 1970, 1975, 1977; U.S. Department of Commerce, Bureau of the Census, Characteristics of the Population: United States Summary (1960, $1970)$; U.S. Department of Commerce, Bureau of the Census, Current Population Reports, Series P-25, No. 643 (January 1977) and No. 541 (February 1975). 
arrested for every one homicide attributed to this group. ${ }^{11}$ In 1975 , age-specific rates of homicide as measured by arrest increase sharply from very low levels in the earlier teens-a total of 142 arrests for 13- and 14-year-olds nationwide in 1975-to rates typical of young adults in the age categories of 18,19 , and $20 .{ }^{12}$

The statistics on rape arrests suggest concentration of offenses in the older teen years, with 17-, 18-, and 19-year-olds arrested at rates that are approximately three times those of the age group 13-15.13 The arrest rate per 100,000 at risk for rape rose modestly during the 1960s and has been stable through the 1970s. For these two serious offenses of violence, the offense rate under 18 is modest when compared with any other form of youth criminality, and while the $1960-70$ growth rate in homicide is substantial, it was growth from a low base. The homicide arrest rate for young adults (ages 21-24) was twice the youth rate in 1975 , and this probably understates the difference in offenses. ${ }^{14}$ Forcible rape, with a higher base rate, experienced more modest relative growth during the period.

The specific rates of homicide and rape arrests reported in table 1 are important only as rough indicators of trends: there is no magic significance to the fact that the number of arrested young people within the FBI's sample of reporting agencies works out to a 14.1 per 100,000 rate in 1975 when compared with the presumed population aged 13-20 during the same year in those areas. In any discussion of "juvenile" or "youth" violence, the specific rate estimate for 1975 would almost double if the arrest rate per 100,000 males were separately reported, ${ }^{15}$ and could be increased even more substantially if an estimated

${ }^{11}$ Unpublished data collected by Joel Eigen (1977). Earlier published data can be found in Zimring, Eigen, and O'Malley 1976.

12 In 1975 there were 2,576 homicide arrests in the 18-20-year age group and 2,423 arrests in the 21-23-year group (U.S. Dept. of Justice, FBI 1975, table 36).

${ }^{13}$ The 17-19 age group showed an arrest rate of 38.8 per 100,000 compared to 13.4 per 100,000 for the 13-15-year group for forcible rape in 1975 (U.S. Dept. of Justice, FBI 1975, table 36).

14 Multiple arrests for a single offense are more likely to occur in the younger age group (Eigen 1977).

16 In 1975 female arrests accounted for 15.6 percent of criminal homicide, 1 percent of forcible rape, 7 percent of robbery and 13.1 percent of aggravated assault arrests (U.S. Dept. of Justice, FBI 1975, table 38). 
crime rate were derived from arrest statistics by estimating the number of offenders not apprehended. ${ }^{16}$ Factoring in the decline in clearance rates would also magnify apparent. increases in arrests over time. ${ }^{17}$ Finally, the growth in homogeneous youth violence could be made to appear still more substantial if the number of arrests rather than the rate of arrests per 100,000 population were used as the measure, because the youth population expanded dramatically during the period under study. ${ }^{18} \mathrm{On}$ the other hand, those seeking to minimize the involvement of young persons in homicide and rape could dramatically lower the estimate by reducing the impact of multiple arrests for the same homicide, ${ }^{19}$ confining the offender sample to those who were in fact convicted, ${ }^{20}$ or by lowering the maximum age included in the sample. ${ }^{21}$ There is legitimate rationale for all these adjustment strategies; there are no precise data available in aggregate form to provide the foundation for any of the computations (except population by sex) required to develop the alternative measures. Thus, no single number can provide anything but a rough indication of the incidence and trends in homicide and forcible rape participation.

But despite the crudeness of the data, and the arbitrary charac-

\footnotetext{
16 Police "clear" a crime when they have identified the offender or have sufficient evidence to charge him or actually take him into custody. In 1975 reported clearance rates were 78 percent for reported murders, 51 percent for forcible rape, 64 percent for aggravated assault and 27 percent for robbery (U.S. Dept. of Justice, FBI 1975 , p. 37).

${ }^{17}$ Clearance rates for reported crimes in 1960 were 92 percent for murder, 73 percent for forcible rape, 76 percent for aggravated assault, and 39 percent for robbery (U.S. Dept. of Justice, FBI 1960).

${ }^{18}$ The national population aged $13-20$ was $21,659,049$ in $1960,30,758,218$ in 1970 , and an estimated 33,590,000 in 1975 (U.S. Dept. of Commerce, Bureau of the Census $1960,1970,1975)$.

19 A Chicago study for 1965-70 found that killings by multiple offenders occurred in 45 percent of the homicides involving offenders aged 15-24 but in only 10 percent of all other homicides (Block and Zimring 1973, p. 8).

${ }^{20}$ In 1974 in Manhattan about 84 percent of juveniles "contacted" by the police did not reach court, and, of those that did, only 14 percent were adjudicated as guilty (see Strasburg 1978, pp. 95-127, and Boland and Wilson 1978, pp. 27-28).

${ }^{21}$ The 1975 statistics show $1,531(8.4$ per 100,000) arrests for homicide and 3,698 (20.9 per 100,000) arrests for forcible rape in the 13-17 age group. By also considering the significantly larger arrest totals for 18-20-year-olds, we find 4,107 (14.6 per $100,000)$ arrests for homicide and $7,972(28.3$ per 100,000$)$ for forcible rape in the 13-20 population (U.S. Dept. of Justice, FBI 1975, table 36).
} 
ter of the methods used to measure rates, the sharp differences in trend noted since 1970 suggest a leveling off which is inconsistent with public perceptions about trends in youth violence.

\section{B. Robbery}

The rate of youth robbery is much higher than rape and homicide and while robbery victimization is concentrated among the young, the poor and minorities, it also threatens large numbers of the old, the middle class, and a broad representation of the community at large (Cook 1976, pp. 175-77; U.S. Dept. of Justice, Nat. Crim. Justice Inf. and Stat. Svc. 1976, pp. 16, 33, $48,64,80)$. Table 2 sets out arrest statistics by age group for robbery, focusing on the period 1960 through 1977. It shows extremely high relative growth in robbery participation from a rather large base in 1960. Robbery arrests increase more modestly between 1970 and 1975 and decline to 1970 per capita rates by 1977. The growth during the 1960 s in reported arrests per 100,000 youth - 109 percent - is substantial but understates the real growth in the incidence of this offense because clearance rates for all major offenses of violence have declined; thus the

TABLE 2

Trends in Robbery Arrest Rates for Offenders Aged 13-20, 1960-77

\begin{tabular}{lcc}
\hline & $\begin{array}{c}\text { Estimated Robbery } \\
\text { Arrests } \\
\text { per } 100,000\end{array}$ & $\begin{array}{c}\text { Percent } \\
\text { Change }\end{array}$ \\
& 118 & \\
1960 & 205 & 74 \\
1970 & & \\
$\begin{array}{l}\text { Change }(1960-70) \\
1975\end{array}$ & 254 & 24 \\
$\begin{array}{l}\text { Change }(1970-75) \\
1977\end{array}$ & 210 & -17 \\
Change $(1975-77)$ & & \\
\hline
\end{tabular}

Sources: U.S. Department of Justice, Federal Bureau of Investigation, Uniform Crime Reports, 1960,1970, 1975, 1977; U.S. Department of Commerce, Bureau of the Census, Characteristics of the Population: United States Summary $(1960,1970)$; U.S. Department of Commerce, Bureau of the Census, Current Population Reports, Series P-25, No. 643 (January 1977) and No. 541 (February 1975). 
number of arrests for every 100 reported crimes has correspondingly decreased (Zimring 1978, pp. 19-20). If one assumes, as I have argued is improper, the same ratio of arrests to crimes for the young as for the not-young, offenders in the 13-20 age bracket are responsible for 245,000 robberies in 1975-55 percent of the aggregate officially reported rate of robbery.

There remains the thorny problem of what kind of robbery is committed by the young and whether the dangerousness of this offense is increasing over time. Victim surveys and self-report studies indicate a persistent tendency for younger offenders, particularly those uniformly classified as juveniles, to rob more often in groups, to use fewer weapons, and to constitute less of a death risk per 100 offenses than older offenders (Cook 1976, pp. 179-80). But only fragmentary data are available to flesh out the aggregate national numbers to give us any clear reading on which of the many forms of robbery are represented, in what measure, in the aggregate total of any year's arrests. Official statistics do not give weapon breakdowns by age of offender, even where the offense results in an arrest (U.S. Dept. of Justice, FBI 1975). Nor is there a special category of robbery with injury used in police reporting. ${ }^{22}$ The Philadelphia cohort study, whose sample of offenses roughly corresponds with the beginning of the time series we are analyzing (1960-63), reports relatively low weapon involvement and modest average seriousness. ${ }^{23}$ Chicago studies concerned with the period 1965 through 1970 provide evidence that robbery committed in the late teen years involved increasing use of firearms and sharp increases in levels of lethality (Block and Zimring 1973, pp. 7-10). A continuation of the Chicago studies suggests an absolute reduction in the lethality of youth robbery since $1970 .{ }^{24} \mathrm{Victim}$ survey data are too new to provide

22 Information supplied by the FBI, Uniform Crime Reporting Division.

${ }^{28}$ The Philadelphia study, which followed the city's male population from birth in 1945 to age 18 in 1963, found 7 percent of its index offenses (injury, theft, or darnage) involved the presence of a known weapon, while less than 2 percent of these offenses resulted in death or hospitalization (Wolfgang, Figlio, and Sellin 1972, pp. 82-84).

24 The lethality of youth robbery may have peaked in 1970 when 78 percent of Chicago robbery homicides were attributed to offenders aged 15-24. That figure dropped to 70 percent in 1971 and rose to 74 percent in 1973 and 1974 (Block 1977, table 4-3). 
the kind of time perspective on patterns of youth robbery that would suit current needs. ${ }^{25}$

Because the robbery arrest rate is moderating during the mid1970 s, it will be of special importance to find out whether the seriousness of youth robbery is abating as the rates are leveling off. ${ }^{26}$

\section{Aggravated Assault}

Most homicide is the outgrowth of violent interactions that would be classified by the police as aggravated assault if a killing did not result. For this reason, rates, patterns, and trends in assaultive violence are of special interest to students of criminality among the young. Unfortunately, translating official statistics on this offense into meaningful trends is a source of particular frustration. Table 3 tells us virtually all that the official aggregate

TABLE 3

Trends in Aggravated Assault Arrest Rates for Offenders Aged 13-20, 1960-77

\begin{tabular}{lcc}
\hline & $\begin{array}{c}\text { Estimated Aggravated } \\
\text { Assault Arrests }\end{array}$ & $\begin{array}{c}\text { Percent } \\
\text { per 100,000 } \\
\text { Change }\end{array}$ \\
1960 & 96 & \\
1970 & 155 & 62 \\
$\begin{array}{l}\text { Change (1960-70) } \\
1975\end{array}$ & 220 & 42 \\
$\begin{array}{l}\text { Change (1970-75) } \\
1977 \\
\text { Change (1975-77) }\end{array}$ & 213 & -3 \\
\hline
\end{tabular}

Sources: U.S. Department of Justice, Federal Bureau of Investigation, Uniform Crime Reports, 1960, 1970, 1975, 1977; U.S. Department of Commerce, Bureau of the Census, Characteristics of the Population: United States Summary $(1960,1970)$; U.S. Department of Commerce, Bureau of the Census, Current Population Reports, Series P-25, No. 643 (January 1977) and No. 541 (February 1975 ).

${ }^{25}$ A part from the pioneering victimization surveys of the middle sixties, the Justice Department began systematic collection of victimization data in 1972 and 1973 (U.S. Dept. of Justice, LEAA 1974).

${ }^{26}$ While age-specific data are unavailable, the rate of robberies involving weapons declined for the total urban population during the 1975-77 period. See Appendix, table B. 
statistics can tell us about aggravated assault by the young since 1960. The arrest rate for non-robbery assaults begins at a high base rate in 1960. Between 1970 and 1975, the arrest rate for aggravated assault increased even more quickly, on an annual basis, than during the preceding decade, in contrast to the flat trends in per capita arrests for homicide and rape. Since 1975, rates of assault arrest have remained quite close to the 1975 peak. Thus aggravated assault is the only violent offense to display sharp increases during the 1970 s that have not been counterbalanced by declines since 1975 .

The divergence of trends between aggravated assault as measured by arrests and homicide is both puzzling and important. Have non-robbery assaults become less lethal among the young? Has police policy shifted toward including less serious events in the assault category? Has the rate of serious aggravated assault remained relatively stable while the rate of less dangerous assault has increased?

The puzzle of divergent trends in assault and homicide is important because of the extraordinary leverage that assault and robbery have in determining trends in total "violent crimes." A 2 percent increase in the rate of reported aggravated assault is the numerical equivalent of more than 25 percent of all homicide arrests among the young in 1975 in any aggregate index of youth violence.

The heterogeneous nature of aggravated assault as an offense category is a particular problem for students of violent crime among the young. Some evidence of the extraordinary variety of assaultive behavior can be gleaned from age-specific data on assault arrests. Over 1,000 arrests of offenders aged 10 and under for aggravated assault are reported in the Uniform Crime Reports in 1975. The police statistics tell us that these are arrests for serious assault, but the same edition of the Uniform Crime Reports indicates only 17 homicide arrests in the national sample for that year in that age group. Table 4 compares homicide arrests and aggravated assault arrests during 1975 by age. From this, the conclusion one reaches about relationships between age and violent crime depends heavily on one's definition of violence. 


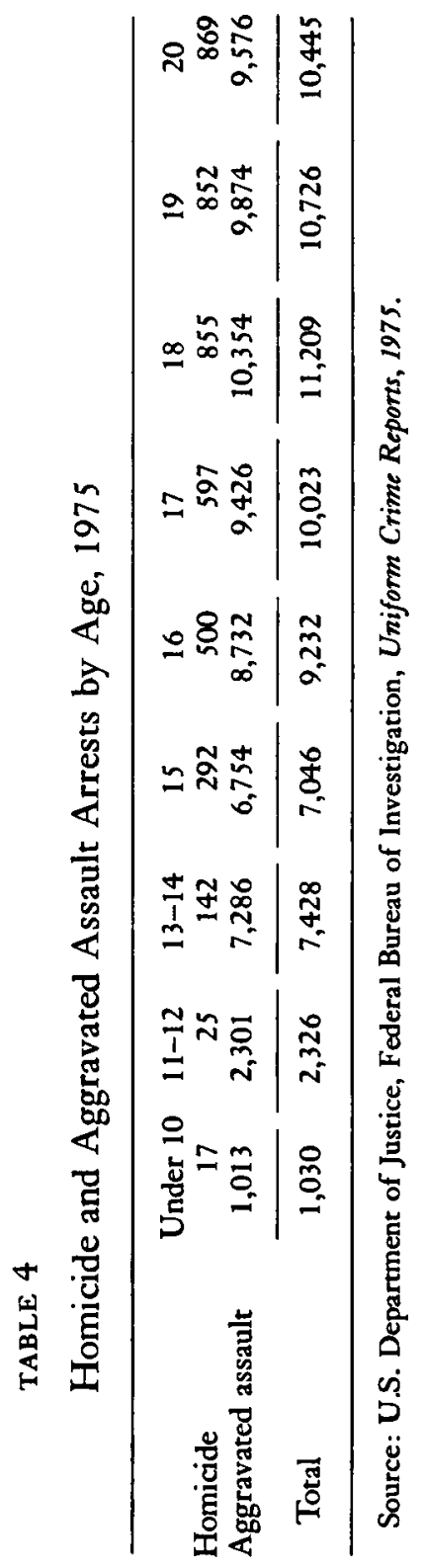


Table 5 shows the concentration of youth violence arrests by crime in large urban areas. Offenses of violence, particularly robbery, are intensely concentrated in the nation's large cities. The offense that displays the smallest relative concentration is aggravated assault, the catholic category. Whether this reflects a wide distribution of both life-threatening and less serious violence cannot be inferred. But it is worthy of note that homicide arrests are three times as frequent in big city youth populations whereas assault arrests are only twice as frequent. It is thus plausible that less serious patterns of assaultive violence are reflected in the arrest statistics for reporting areas outside major cities. ${ }^{28}$

Table 6 shows the distribution by sex of violence arrests. To some extent the dominance of males in arrest statistics may reflect a reluctance on the part of the police to arrest girls or to charge an arrested female with an offense of violence. But the persistence and magnitude of the difference between the sexes in violent crime suggest that this difference is something more than the product of chivalry in the criminal justice system.

Similarly, available statistics indicate that urban minority youth are disproportionately involved in violent crime, although

TABLE 5

Violent Crime by City Size, 1975

(Arrests per 100,000)

\begin{tabular}{lccc}
\hline & $250,000+$ & All Other & Ratio of \\
City Size & Areas & City/Other \\
Homicide & 21.3 & 6.7 & 3.2 \\
Rape & 56 & 20 & 2.8 \\
Aggravated assault & 369 & 187 & 2.1 \\
Robbery & 678 & 110 & 6.2 \\
\hline
\end{tabular}

Source: U.S. Department of Justice, Federal Bureau of Investigation, Uniform Crime Reports, 1975.

${ }^{28}$ See table 5. It should be noted, however, that fatal attacks stemming from robbery are reflected in the homicide arrest statistics while nonfatal robbery attacks are not reflected in the aggravated assault arrest statistics. Since robbery is more common in large cities, this statistical quirk may also influence the variations in ratios of homicide to assault. 
Arrest statistics indicate 2,300 aggravated assaults and homicide arrests in the age bracket $11-12$ as compared to 10,000 such arrests for 17-year-olds. In this aggregate measure of total violent crime, 11-12-year-olds would appear responsible for a fourth of the aggravated assaults and homicides attributable to 17-year-olds. Yet the death risk from attack reflected in these statistics varies dramatically. Seventeen-year-olds are arrested for homicide twenty-four times as often as 11-12-year-olds even though they are approximately half the size of the younger population at risk. Assaultive violence among 17- and 18-year-olds produces about one-third more arrests than among the age group 11-15, but it is responsible for three times the number of homicide arrests.

This roundabout investigation of patterns of aggravated assault suggests that any comparison of arrests in this category over time or between jurisdictions is hazardous and that any index of violent crime which includes undifferentiated measures of aggravated assault will be rendered opaque by the mixture of serious and less serious events agglomerated in the overall pattern. The index of violent offenses, itself a reform from the even broader "crime index," 27 requires further specification before it can be a useful social indicator. And much greater detail on the nature of assaults known to the police and resulting in arrest will be needed before trends in this offense can be meaningfully discussed.

With this national level survey as background, the remainder of this section provides a brief sketch of the distribution of youth violence among the youth population and provides some data on the impact of demographic shifts on likely future trends.

\section{Youth Violence and the Youth Population}

To the extent that official statistics mirror reality, serious youth violence occurs more often in cities than in non-urban areas, involves boys far more frequently than girls, and is concentrated among low social status, ghetto-dwelling urban youth.

27 The 1967 President's Commission targeted the four violent crimes-willful homicide, rape, robbery, and serious assault-as a special area of concern (President's Commission on Law Enforcement and Administration of Justice 1967, pp. 3-4). 
the official statistics probably overstate the difference between the races (Zimring 1978, pp. 39-42). Table 7 shows the ratio of black to white arrest rates per 100,000 youths by crime for five cities in the census year of 1970 . The violent offenses of homicide and robbery show heavier racial concentrations than property offenses of burglary and auto theft. How much of the racial differences noted with respect to violent offenses can be attributed to selective enforcement, differences in socioeconomic class, and other unaccounted variables has not been adequately

TABLE 6

Distribution of Violence Arrests for Persons under 18 by Sex and Offense (Excluding Rape), 1975

\begin{tabular}{lccc}
\hline & Percentage & Percentage & Total \\
& Male & Female & Arrests \\
Homicide & 90 & 10 & 1,373 \\
Robbery & 93 & 7 & 40,796 \\
Aggravated assault & 84 & 16 & 30,858 \\
\hline
\end{tabular}

Source: U.S. Department of Justice, Federal Bureau of Investigation, Uniform Crime Reports, 1975.

TABLE 7

Ratio of Black to White Arrest Rates per 100,000 Youths by Crime in Five Cities, $1970^{*}$

\begin{tabular}{lc}
\hline & Black/White \\
& Ratio \\
Homicide & 7.2 \\
Robbery & 8.6 \\
Burglary & 3.9 \\
Auto theft & 3.0 \\
\hline
\end{tabular}

* Boston, Chicago, Cleveland, Dallas, Washington, D.C. Source: Franklin Zimring, "Crime, Demography and Time in Five American Cities," paper prepared for the Hudson Institute Project on Criminal Justice Futures (May 1976). 
investigated. ${ }^{29}$ But the concentration of offenses of violence in urban areas among minorities is an important partial explanation for the explosion of violent youth crime in the 1960s. The fifteen years from 1960 to 1975 were characterized by a large increase in the youth population, an increasing concentration of the young in urban areas, and a huge increase in the minority youth population in core cities (Zimring 1975, chap. 3). These population changes occurred in a social setting when crime rates for all significant age groups were increasing. ${ }^{30}$ Given generally higher crime rates as well as large increases in the population at risk, a substantial increase in violent youth crime was predictable. The increases that occurred between 1960 and 1970 were, however, much greater than the most sophisticated demographic projections would have predicted, because rates per 100,000 of major crimes of violence increased dramatically. ${ }^{31}$ During the $1970 \mathrm{~s}$ it is probable that age- and race-specific rates of urban youth violence did not increase and there is some evidence of a decrease in rate. ${ }^{32}$

Over the next decade, if we assume that the present concentration of violent crime continues, the declining youth population should be responsible for a smaller volume of total youth criminality. However, the volume of violent crime should be less responsive to the overall decline of the youth population because

${ }^{29}$ The Philadelphia cohort study did attempt to control its population data for differences in socioeconomic status and disposition of offenders (Wolfgang, Figlio, and Sellin 1972, pp. 47-52, 218-26).

${ }^{30}$ The FBI reported a 233 percent increase in total index crimes per 100,000 inhabitants over the 1960-75 period. The rate per 100,000 of violent crime (murder, forcible rape, robbery, and aggravated assault) rose 199 percent (U.S. Dept. of Justice, FBI 1975, table 2).

${ }^{21}$ See tables 1, 2, and 3.

32 Clearance rates for homicide declined from 86 to 78 percent from 1970 to 1975 . To the extent that this accurately reflects a trend in clearance rates for youth population, the 4 percent increase in arrests would reflect a 15 percent increase in offenses. Similarly, forcible rape clearance rates declined from 56 to 51 percent, and if this accurately reflects a trend for youth, the 1 percent rape increase would represent an 11 percent increase in offenses. By contrast, similar manipulations of 1960 and 1970 data would yield an estimated increase of 98 percent during that period for homicide offenses and 52 percent for rape. It is important to note, however, that clearance rates used in these computations are arbitrary and aggregate. Age-specific data is not available. Furthermore, given the changing racial composition of urban areas over the period 1970 to 1975 , one would expect increasing aggregate youth violence even if race-specific rates remained constant (U.S. Dept. of Justice, FBI 1960, 1970, 1975, 1977). See Appendix, table C. 
the population of urban-dwelling minority males will not decline dramatically in the 1980s (Zimring 1975, chap. 3). What one would expect, therefore, is a greater drop in the more democratically distributed property crimes than in such offenses as robbery and homicide. There is some evidence, however, that offenses of violence are decreasing, and that this decrease is due in large measure to declining rates of youth violence. Nationwide, the homicide rate in 1977 was down almost 10 percent from 1975 levels. ${ }^{33}$ Since 1975 , individual cities have reported sharp decreases in homicide and robbery rates. ${ }^{34}$

There is no persuasive reason to believe the recent decreases in youth violence can be attributed solely to demographic shifts. The same can be said for the moderating rate of very serious youth violence that appears to have characterized much of the 1970s. The 1960s witnessed a period when sharp increases in youth violence could not be explained solely by changes in the youth population. The 1970s witnessed moderating rates of violence per capita. We are left in the happy if scientifically frustrating circumstance of confronting good news which the present level of social science understanding cannot explain.

II. Measuring Youth Violence: Current Methods and Limits

Recent debate about social policy toward young offenders contains frequent references to estimates of the volume, seriousness, and concentration of serious youth violence. Unfortunately, references to the "facts" of youth crime are both highly selective and uncritical in much of the literature. This section surveys existing methods of measuring youth crime. The following section addresses the relevance of existing data to three key policy issues and recommends supplemental approaches to the measurement of youth violence that would contribute to informed public policy discussion.

${ }^{33}$ The national homicide rate fell from 9.6 per 100,000 in 1975 to 8.8 per 100,000 in 1976 (U.S. Dept. of Justice, FBI 1976, table 2).

24 Philadelphia and Detroit showed dramatic decreases in estimated homicide and robbery rates between 1975 and 1977. In Philadelphia homicides dropped from 573 to 389 . In Detroit homicide rates decreased from 47 to 37 and robbery rates decreased from 1,597 to 1,218 per 100,000 (U.S. Dept. of Justice, FBI 1975, 1977). 


\section{A. Official Statistics}

The principal tool for measuring age-specific violence is the series of annual aggregate arrest statistics forwarded by local police departments and reported by the FBI. Supplemental tools include occasional "cohort" studies sampling subjects from the general population and using police arrest statistics as a measure of criminality (Wolfgang, Figlio, and Sellin 1972; Polk, Frease, and Richmond 1974, pp. 84-97; Shannon, unpublished), studies of juvenile court intake (Cohen 1975; Strasburg 1978), self-report studies which survey samples of the youth population and ask them to report on the frequency and seriousness of their criminal acts (Gold and Reimer 1975, pp. 483-517), and surveys of the victims of crime that include victim estimates of the age of offenders. ${ }^{35}$ While the variety of different measures of youth crime is substantial, the data base that has emerged is insufficient.

In the best of years, official statistics on arrest rates for violent crimes are seriously flawed. Whatever biases are built into the policing process are passed on in official statistics (Gold and Reimer 1975). For nine out of every ten youth violence arrests, there is no detail on the seriousness of the particular offense. ${ }^{36}$ Statistics forwarded by local departments on the incidence of crime are audited by the FBI, but there is evidence that statistics on arrests are not similarly scrutinized. All these well-known difficulties are compounded by dramatic shifts in the number of agencies reporting age-specific arrest statistics and the periodic omission of major cities that make year-to-year comparisons in youth violence a hazardous occupation (Zimring 1978, pp. 15, 22-23). One does not have to read far back in history for examples of "peculiar" years in youth arrest reporting statistics. The present analysis is concerned with 1975 and 1977 but not 1976 as the end years because the 1976 data do not include Chicago arrest data. ${ }^{37}$ By contrast, the 1974 Uniform Crime

\footnotetext{
${ }^{35}$ Victim estimation of offender age is collected by the Bureau of the Census but not published in the major criminal victimization surveys (Dodge, Lentzner, and Shenk 1976, pp. 1-26).

${ }^{36}$ See text at pp. 72-73, above.

${ }^{37}$ Information supplied by the Chief of the Statistical Division, FBI Uniform Crime Reporting Bureau, September 1977.
} 
Reports did include the city of Chicago but did not include arrests from a host of police agencies representing a population of more than 20.million who were temporarily omitted from the reporting sample. ${ }^{38}$

\section{B. Alternative Measures}

The most important new method of measuring American delinquency is a series of cohort studies that depend on birth or school statistics to capture a representative sample of an area's population and use police statistics to estimate the incidence and distribution of delinquent behavior as the sample gets older (Wolfgang, Figlio, and Sellin 1972, pp. 27-52). Such an enterprise will reflect whatever biases influence the police decision to arrest, but the use of individual offense narratives rather than aggregate arrest statistics allows the researcher to follow individual careers, to make specific assessments of the seriousness of individual acts that come to the attention of the police, and to mesh data from law enforcement records with data on educational attainment, socioeconomic status, and other presumed correlates of delinquent behavior (Wolfgang, Figlio, and Sellin 1972, pp. 39-52; Jensen 1976, pp. 379-87). A second further advantage of the cohort strategy is the opportunity to study nondelinquent youth of the same age. The first major American cohort enterprise, a study of Philadelphia youth born in 1945, was published in 1972. It is, at present, the single most important data base for assessing the incidence and distribution of youth violence (Boland and Wilson 1978; Jensen 1976; Strasburg 1978). Unfortunately, research of this character is expensive if sample sizes are to be sufficiently large to permit the study of relatively low incidence offenses, and even retrospective studies are time-consuming if performed with care. Thus the Philadelphia cohort that is frequently discussed in contemporary policy debates about youth violence turned 18 in 1963, when rates of youth violence were about half current levels. The expense associated with large sample cohort

38 The 1974 national age-specific arrest data were based on reports from 5,298 agencies covering an estimated population of 134 million. In 1973, 6,004 agencies (155 million population) reported (U.S. Dept. of Justice, FBI 1973 and 1974, tables 30 and 34$)$. 
studies means that relatively few such studies exist. The effort necessary to perform cohort analysis suggests that unless patterns of youth violence are stable over time, cohort research may be "dated" by the time it is completed. Full-scale longitudinal studies can help solve this problem, but these sustained efforts have not yet become an established part of American criminology. ${ }^{39}$ Still, the cohort approach is properly serving as a model for contemporary replications in American urban and rural areas. If such studies had been made earlier and more frequently, far more reliable information on trends in youth violence over time would currently be available.

Studies of juvenile court intake are faster, less expensive and less informative than full-blown cohort enterprises. ${ }^{40}$ By definition, such studies encompass suspected offenders only, and typically involve relatively small samples of the juvenile intake and correspondingly low levels of violence arrests. ${ }^{41}$ Most of the studies published to date depend solely on juvenile court records, and these records contain very little information on cases that are informally disposed of before juvenile court petitions are filed (Strasburg 1978, p. 88). For example, in Paul Strasburg's study of the Manhattan Juvenile Court, a substantial number of police arrests for index violence offenses were informally disposed of, a phenomenon that suggests the residual sample of violent offenses was biased to some extent. This type of policy decision in the juvenile court also suggests what the above discussion of "heterogeneous" juvenile violence has implied: many officially recorded youth violence arrests stem from less than heinous behavior. Studies of juvenile court intake

${ }^{30}$ For a discussion of longitudinal studies in the United States and elsewhere, see David Farrington's essay in this volume.

${ }^{10}$ See Cohen (1975) for analysis of juvenile processing in the Denver County, Colorado, Memphis-Shelby County, Tennessee, and Montgomery County, Pennsylvania, courts; see also Strasburg (1978, pp. 88-112) concerning Manhattan and Westchester Counties in New York and Mercer County in New Jersey.

${ }^{41}$ Strasburg's Manhattan County sample of 221 juveniles in 1974 came from 13,000 police contacts leading to 4,313 arrests leading to 2,124 petitions to juvenile court. The Westchester sample of 111 juveniles was chosen from 636 petitions resulting from 2,293 arrests from 6,000 police contacts; the Mercer County sample of 178 derived from 6,717 contacts, 2,720 arrests, and 2,363 petitions (1978, p. 96). Cohen's study covered all juvenile cases referred to the courts in 1975:5,684 in Denver, 6,596 in Memphis-Shelby, 1,302 in Montgomery County (1975, pp. 15-20). 
are relatively recent, and it is thus difficult to use the data generated from such studies to address trends in youth violence over time.

\section{Survey Research}

Self-report studies of potential young offenders and the victims of crime are another supplement to official statistics emerging in the literature. "One shot" studies of adolescents, students, and adults who report on their criminal activity have long been a staple of American sociological research. An effort to assess the criminal behavior of a national sample of American adolescents in two different years, 1967 and 1972, was reported by Martin Gold and David Reimer in 1975 (Gold and Reimer 1975). Asserting that "official data on delinquency are tied so loosely to the actual behavior of youth that they are more sensitive to the changes in the measurement procedures than they are to the object of measurement," Gold and Reimer (p. 514) conclude that per capita rates of delinquent behavior, other than alcohol and drug-taking, declined during the period 1967 to 1972. Paul Strasburg in his review of violent delinquency finds the results of this study "surprising and significant" (1978, p. 21), and concludes that "these findings run counter to the trend in the FBI's Uniform Crime Reports for the same five year period" (p. 22). In fact, at least as pertains to violent youth criminality, there may be little in the self-report study that casts doubt on official statistics. In the first place, the national sample interviewed by Gold and Reimer was small $(1,395$ youth between ages 11 and 18 including fewer than 500 males over the age of 15) (1975, pp. 484-85). Second, 29 percent of eligible respondents were not interviewed, and more than two-thirds of the non-interviews were the result of refusals by the youth, or both the youth and his parents, to participate. Whether "refusers" were more apt to be offenders is not known, but the likelihood cannot be lightly dismissed. Third, particular high risk groups were not heavily represented: there were fewer than 30 black males over the age of 15 in the sample. ${ }^{42}$ Given the

${ }^{42}$ Approximately 36 percent of the Gold and Reimer sample were over 15 and only 87 of 1,395 in the sample population were black males (1975, pp. 484-85). 
low incidence of serious youth violence it is therefore altogether appropriate that no serious offense of violence was listed in the schedule of behavior that the youth sample was asked to respond to.

Surveys of crime victims add important if imprecise perspectives to offender surveys and official statistics on youth violence. A recent national survey on crime victimization asked those who reported being victims of robbery and assault to estimate the age of the offender or offenders responsible where face-to-face confrontation made such an estimate possible. ${ }^{43}$ This survey, with a much larger sample than any existing self-report offense studies, covered both offenses that were reported to the police and those not reported. For the majority of crimes that were not cleared by arrests, the survey provides some data on the approximate age of the offender and the characteristics of the offense. The number of victims is sufficiently large for an offense such as robbery to give something of a national portrait of the approximate age of offenders. The study provides some basis for concluding that younger offenders are less frequently armed, more frequently in groups, and more likely to pick "softer" targets than are older offenders (Cook 1976, pp. 178-80). The sample of offenses in the national crime survey was evidently not sufficiently large to provide confident estimates of how these patterns vary by city size, ${ }^{44}$ and (as noted earlier) the victim surveys do not extend far enough back in time to provide an independent indicator of trends over time.

\section{Linking Measurements}

When all these supplemental measures are added to the existing base of official arrest statistics, an incomplete and occasionally inconsistent portrait of youth violence emerges. The small number of supplemental studies, the varying methodologies, and the inconsistent findings do not permit a national portrait of youth violence to be drawn in which the different indices are

${ }^{48}$ See n. 35.

"The victimization survey statistics on offenders cited by Cook are aggregate totals from the National Crime Panel Survey of twenty-six cities (Cook 1976, pp. 178-80). 
joined together so that the whole exceeds the sum of its parts. Instead, the primary data used in any discussion of trends or patterns of youth violence come from aggregated arrest statistics, and supplementary methods of study are used to interpret or argue about what the aggregate statistics mean. Attempts to link the products of supplemental methods of study to official statistics almost always involve assumptions that seem unwarranted about the continuity of trends over time and the similarity of patterns in different areas.

Indeed, there may be no single "national" portrait of youth violence or any uniform set of trends that can be generalized across regions and different population groups. The ebb and flow of aggregated national totals may reflect a wide diversity of patterns and trends. To date, however, empirical studies of youth violence are insufficient in number and quality to test even this hypothesis. Thus, while data play an important role in current debates about whether there is a wave of violence in the suburbs, or growth in the number of young career violent offenders, or a "breakdown" in the juvenile justice system, the information base available at present is too tentative and too internally inconsistent to bring such issues to resolution. In the pages that follow, these deficiencies in information will be a major theme animating discussion of three issues that have emerged in recent literature and in public debate.

\section{From Statistics to Policy? Three Key Issues}

Any short list of significant issues concerning youth violence will be necessarily incomplete and reflect the biases of both the listmaker and the times. In this period of intense debate about public policy toward serious young offenders, three questions appear to deserve detailed discussion.

1. How concentrated is serious youth violence among sectors of the youth population and how successfully can we predict the recurrence of violence in individual cases?

2. What is the relationship between variations in social control policy and the incidence of youth violence?

3. To what extent can trends in violence by the young be 
used as a leading indicator of future trends in aggregate rates of violent crime?

It is my view that existing data are insufficient to provide acceptable answers to these questions.

\section{A. The Concentration and Predictability of Youth Violence}

Self-report studies indicate that the vast majority of American young people violate the law during adolescence. Official statistics on arrests and juvenile court intake suggest a pool of officially identified and suspected offenders in the millions (Zimring 1978, pp. 178-80). Yet any intervention strategy-punitive, preventive, or rehabilitative - must necessarily be directed at smaller numbers of young offenders. In some reform proposals, selectivity is urged in relation to the seriousness of the most recent offense committed by a particular adolescent that leads to his conviction in juvenile or criminal court. In its pure form, this proportional emphasis would focus, primarily, on the seriousness of the youth's offense and would be more concerned with retributive justice than with the prediction of dangerousness. ${ }^{45}$

A second approach, designed to enhance crime prevention, would attempt to isolate the young, violent career criminal regardless of his age. While detailed policy recommendations are not put forward in current literature, the broad outlines of such an approach were recently suggested by Barbara Boland and James Q. Wilson:

[p] erhaps there should be a two-track system, but with the tracks defined by the nature of the criminal career rather than by the age of the offender. One system would deal, largely by non-custodial means, with routine, intermittent

45 The American Bar Association's proposed juvenile justice standards classify juvenile offenses according to criminal penalties applicable to adults. An offense normally punishable by death or life imprisonment is a class one juvenile offense punishable by a maximum of two years' confinement in a secure or nonsecure facility or three years' conditional freedom. An offense normally punishable by a prison term of six months or less is a class five juvenile offense, punishable by a maximum of two months in a nonsecure facility if the juvenile has a prior record (a class one, two, or three offense or three class four or five offenses) or conditional freedom for six months (Institute of Judicial Administration and American Bar Association, Juvenile Justice Standards Project 1977a, Parts V-VI). 
offenders or those with short criminal records. The other would deal with serious, intensive offenders and would almost invariably employ close supervision or custody. (1978, p. 34)

To have any significant impact on violent crime, such an approach would require a substantial number of young career offenders who $(a)$ are responsible for a large share of violent crime and $(b)$ can be identified in advance. Empirically, such a two-track system works best when violent criminality is heavily concentrated among a small segment of juvenile offenders and is persistently committed by those offenders, and when such future violent criminality can be predicted from a particular pattern of present offense or prior criminal history.

The available evidence on these related topics is ambiguous. Clearly, it is far less decisive than the recent Boland and Wilson treatment of the subject would lead a reader to conclude. The most often quoted finding of the Wolfgang, Figlio, and Sellin study is that "the vast majority of serious crimes" in the sample were committed "by the approximately six percent [of the sample] who are chronic offenders" (Boland and Wilson 1978, p. 32). At first glance, this 6 percent statistic suggests extreme concentration and appears to imply a high capacity to predict serious future criminality. First impressions can be misleading however. Six percent of a population of young males is a large number of offenders indeed, too large for a general application of intensive social control measures. Further, the 6 percent incidence of chronic offensivity is associated with a rate of violent criminality approximately half that of more recent years. ${ }^{46}$ Finally, chronic offenders in the Philadelphia study are defined in terms of total "index offense" arrests, and the majority of these arrests are for nonviolent property offenses. One searches the original cohort study in vain to find strong evidence of a large number of identifi-

\footnotetext{
46 The average estimated annual arrest rate per 100,000 youths aged 13-20 was 249 for the four violent crimes during 1960 to 1963, the period when the Philadelphia cohort passed through the ages of 15-18. The annual rate was an estimated 491 per 100,000 for the period 1974 to 1976 (U.S. Dept. of Justice, FBI 1977).
} 
able youthful offenders specializing in violence. Wolfgang, Figlio, and Sellin concluded (1972, p. 250):

The offense transition matrices appear to be independent of offense number, and in fact, the same process seems to operate at each stage in the offense histories. There is no "break" after which the offenders specialize along some discernible pathways. Indeed, with the exception of a small tendency of like offense repetitions (particularly for theft offenses), the choice of the next offense follows the first offense probability vector as mentioned above.

This is an unpromising finding for those who are interested in the early identification of career violent offenders.

Other studies have been more successful in finding concentration and (to a lesser degree) specialization in criminal careers, but only through the judicious use of hindsight rather than forward predictions of dangerousness. The RAND Corporation study of 49 repetitively violent offenders currently incarcerated as adults for robbery found that those serious adult offenders had had extensive juvenile careers and a large number of offenses including a substantial number of robberies (Petersilia, Greenwood, and Lavin 1977). It was, of course, impossible in a sample selected for its serious adult criminal careers to know what factors could have predicted the kind of criminal involvement which that particular group experienced, because individuals with careers of youth violence could not be included in the sample unless they had persisted in repetitively violent behavior in developing years. (It is of more than passing interest that this RAND study also can not be cited as evidence that juvenile offenders are apprehended less frequently per 100 crimes-as Boland and Wilson have attempted to do [1978, p. 25] -because of the bias built into the sample selection. Since only individuals who have been repetitively apprehended as adults are included in the RAND sample, the sample consists of a prescreened group of unlucky as well as persistently criminal offenders. Because juvenile records were not considered in drawing the sample, the same propensity to be apprehended cannot be assumed for the sample's juvenile as opposed to adult criminal careers.) 
There is, at present, insufficient evidence of the extent to which youth violence is extensively concentrated in a relatively small pool of career offenders. Further, no particular offense or series of offenses is an efficient predictor of future violence in a representative sample of young offenders. The younger the age at first arrest, and the more frequent the number of arrests or convictions, the greater the propensity toward future criminality, violent and nonviolent. To date, however, there is little evidence of the kind of intense specialization that would create maximum impact for a program that was focused on repetitively violent offenders.

Yet it would be foolish to deny, or deny the importance of, the intense concentration of serious violent crime among poor, minority, urban-dwelling males. In strict logical terms, groups do not have crime rates. Individuals either violate laws or they do not. Thus, to speak of blacks, males, 16-year-olds or any other aggregate population that shares a common demographic quality as having a "crime rate" is misleading. It is particularly misleading because the labels listed above produce an incomplete and dangerously distorted portrait of the actual distribution of serious youth violence. A primary future research task relating to the concentration of youth violence is to disaggregate the macrovariables used in common discussion and to examine the large variations that exist within demographically similar groups with different rates of criminal activity.

In logical terms the search for the answer to the question, "How concentrated are crime rates?" would lead to the individual level. But it is also important to know how many young offenders and what proportion of the population within the larger demographic socioeconomic subgroups are responsible for much of reported serious violent youth criminality. Simply combining sex, age, race, and socioeconomic status is a dangerously incomplete method for addressing the real concentration of youth crime. Any such limited approach both overstates the general propensity toward crime among the group under study and understates the concentration of offenses among particularized subgroups aggregated into the larger whole. At minimum, geographic and more 
refined social status and achievement measures must be added to the creditable cohort studies initiated in Philadelphia. ${ }^{47}$ This kind of information is important even if it will not produce clear predictable pictures of career violent offenders on which intensive social control measures can be based.

Research of the kind described above will also provide information on the onset, duration, and intensity of careers in violent crime. The questions are clear: When do adolescents turn to violent crime? Are there patterns of specialization associated with violent young offenders or is there frequent crime "switching"? What is the frequency of commission of violent crime for those young offenders who persistently commit such acts? How long do violent young offenders persist in committing offenses? These empirical questions are high priority candidates for research support. It is also important to recognize how little is presently known about such topics. All too frequently, contemporary discussions of youth crime policy assume we know much more about these topics than a detailed review of existing research reveals. One of the most important contributions of future study will be a shift in focus away from "the violent young offender" to the variety of different types of violent offenders who may have importantly different criminal careers.

\section{B. Does Social Control Make a Difference?}

Most disputes about whether juvenile and criminal courts have failed to cope effectively with youth violence contain implicit assumptions about the effects of alternative (usually more punitive) mechanisms of control in reducing the incidence of violent crime. At the heart of such debate are questions about the deterrent and incapacitative effects of sanctions, particularly incarceration, and the marginal benefits that could be expected from policies that place a higher priority on crime control.

Yet evidence on the marginal effects of increased incarceration is tentative, not specific to youth, and subject to differing interpretations. After a long period of neglect, social and policy

${ }^{47}$ See Wolfgang, Figlio, and Sellin (1972, pp. 47-65) measuring socioeconomic status and educational background of the cohort members. 
scientists have begun to address the issue of measuring the deterrent and incapacitative effects of punishment. To date, the results have been mixed (National Academy of Sciences 1978).

So far, the rekindled interest in deterrence and incapacitation has been confined to the study of sanctions delivered by the criminal courts. The impact of variations of social control strategy on youthful offenders is a neglected area of research. Paradoxically, it may be possible to gain more insight about the marginal deterrent impact of sentence severity by studying variations in social response to youth crime than by studies of variations in sanctioning policies directed at adult offenders. The fact that young offenders age out of the juvenile justice system in New York on their sixteenth birthday but are retained until the age of 18 in Pennsylvania ${ }^{48}$ is a natural opportunity to explore whether juvenile and criminal courts deliver substantially different levels of punitive sanctions and whether whatever difference is noted has any impact on age-specific patterns of violent criminality. The existence of waiver provisions in the great majority of states may be seen as somewhat confounding this type of analysis, but recent research has shown that for an offense such as robbery, very few juvenile offenders are waived to criminal courts. ${ }^{49}$

To date, there has been no systematic study of the general deterrent impact of variations in sanctions available for young offenders and only occasional pilot studies on the incapacitative impact of sanctions presently delivered by juvenile courts. Studies by Stevens Clarke (1974), and John Conrad and his associates $^{50}$ tend to suggest that the incapacitative effects associated with present policies affect a low proportion of total youth crime, but little specific analysis has been done on the issue of youth violence (Van Dine, Conrad, and Dinitz 1977).

${ }^{48}$ N.Y. Jud. Law \$712(a), (b) (McKinney) (1976); Pa. Stat. Ann. tit. 11 \$50102(1) (Purdon) (1972).

19 Joel Eigen (1977) has found that fewer than 2 percent of the juveniles arrested for robbery are waived to adult courts.

${ }^{50} \mathrm{~A}$ study of the Columbus, Ohio, cohort and effects of incapacitation of chronic offenders has now been published (Hamparian, Schuster, Dinitz, and Conrad 1978). 
If the sanctions delivered to young offenders make relatively little difference in crime rates, the juvenile justice system can make decisions which balance retributive community needs against policies of avoiding stigma and facilitating chances for young offenders to develop within the community. If the crime preventive potential of variations in sanctions is high, policy toward youth violence faces harder choices. In such a setting, the juvenile justice system must balance the interests of potential victims against the interests of young offenders, for the state has a positive obligation to protect both groups. In either case, it is far better to build toward estimating the deterrent and incapacitative potentials of various alternative strategies toward young violent offenders than to operate juvenile and criminal court systems essentially in the dark. If hard choices are to be made, they should be based on data rather than on conjecture. Here, as in the discussion of the concentration and predictability of violent crime, current commentaries on the topic tend to assume there is more reliable evidence available than is the case.

\section{Youth Violence as a "Leading Indicator"}

Intuitively, there is reason to believe that the involvement of adolescents in violent criminality may serve as a leading indicator of future trends in aggregate rates of violence in much the same way that certain indices of economic behavior are believed to forecast future trends in the general economy. The peak ages for serious violent crime occur in late adolescence and early adulthood, some years after youth participation in violent crime becomes substantial. If trends among a particular cohort of offenders in their younger years are predictive of relative rates of violence in their later years, one would expect that the earliest indications of an upward or downward shift in aggregate violence could come from reliable data on trends in violence among early and middle adolescents.

But more than intuition is needed to test this hypothesis. Careful and systematic study that encompasses both the period of explosive growth in violence and the more recent leveling-off phenomenon is a necessary element in a balanced agenda of youth 
crime research. Cursory inspection of aggregate arrest data reported to the FBI does not provide strong support for the "leading indicator" hypothesis. Males aged 21-24 show increasing violence arrest rates during the 1960 s, followed by a pattern of moderation (1970-75) and decline (1975-77) that parallels the younger population at risk. ${ }^{51}$ But the age categories, time periods, and arrest samples are not sufficiently refined to provide a fair test of the "leading indicator" thesis. Studies of a series of samples in individual cities are a more promising if more expensive approach. Such studies are well worth the effort. In an area where aggregate trends are difficult to predict and almost impossible to explain, any development of plausible leading indicators would be a major advance. And if youth violence rates are not a good predictor of offense rates in the same population some years hence, the implications for criminological theory would be profound.

\section{Conclusion}

This is a difficult but interesting period for students of youth violence. The upward trend during the 1960s in violent youth criminality remains largely unexplained even as we are experiencing a period when the fever chart of officially reported violent youth crime is moderating. Youth violence is volatile; it is still too early to declare any victory in the war on violent youth criminality. But it is worthy of note that rates of some forms of violent youth criminality have been stable for a longer period than the intense policy debate about juvenile and criminal justice would suggest.

The gap between public perceptions and recent trends may be explained on a number of grounds. Even if the rate of youth violence is coming down on a per capita basis, the expanding youth population has led, until quite recently, to an expanding number of offenses. ${ }^{52}$ The non-young may therefore be unconcerned with

\footnotetext{
s1 See Appendix, table D.

${ }^{62}$ Arrest rates for violent youth crimes may have decreased (table 1, homicide and rape) or increased more slowly since 1970 than before (tables 2 and 3, robbery and aggravated assault), but the youth population aged 13-20 expanded from 30,758,214 in 1970 to an estimated $34,300,000$ in 1975 . Therefore, the total number of arrests increased between 1970 and 1975 . See Appendix, table E.
} 
rates of per capita criminality if their own chances of becoming victims of youthful offenders are increasing on a statistical basis. More important, I suppose, is the gap between symbol and substance that pervades public discussion of crime and criminal justice. The violent young offender remains a threat on the streets of our cities. But the image of the violent young offender that animates policy and political debates is not simply a faithful reflection of statistical realities. It also reflects a complex amalgam of generational, racial, and other societal conflicts which pervade urban American life. In the end, fear of the young will moderate only if these larger social anxieties can be ameliorated. Yet any sustained decline in youth crime may contribute to a more general abatement in social tensions. If this occurs, it will be the most important benefit that fluctuations in the rate of crime can produce in the coming decade.

APPENDIX

TABLE A

Arrest Rates and Totals, 1975

\begin{tabular}{lcccc}
\hline & Estimated Arrests & \multicolumn{2}{c}{ Total Arrests } \\
& \multicolumn{2}{c}{ per 100,000} & \multicolumn{2}{c}{ Reported } \\
& $13-17$ & $18-20$ & $13-17$ & $18-20$ \\
Robbery & 233 & 289 & 41,275 & 30,433 \\
Aggravated assault & 182 & 283 & 32,198 & 28,904 \\
\hline
\end{tabular}

Source: U.S. Dept. of Justice, FBI Uniform Crime Reports, 1975. 
TABLE B

Known Robberies by Weapon,

Total Urban Population, 1975-77

(Rates per 100,000)

\begin{tabular}{lrrc}
\hline & & & Percent \\
& 1975 & 1977 & Change \\
Strong-armed & 113 & 98 & -13 \\
Firearm & 140 & 108 & -23 \\
Knife/cutting instrument & 41 & 35 & -15 \\
Other weapon & 25 & 23 & -8 \\
\hline
\end{tabular}

Source: U.S. Dept. of Justice, FBI Uniform Crime Reports, 1975, 1977.

TABLE C

Clearance Rates

(Percent)

\begin{tabular}{lcccc}
\hline & & Forcible & & Aggravated \\
1960 & Homicide & Rape & Robbery & Assault \\
1970 & 92 & 73 & 39 & 76 \\
1975 & 86 & 56 & 29 & 65 \\
1977 & 78 & 51 & 27 & 64 \\
& 75 & 51 & 27 & 62 \\
\hline
\end{tabular}

Source: U.S. Dept. of Justice, FBI Uniform Crime Reports, 1960 1970,1975 and 1977.

TABLE D

Trends in Violent Crime Arrest Rates for Offenders Aged 21-24, 1960-77

\begin{tabular}{lccrc}
\hline & \multicolumn{4}{c}{ Estimated Arrests per 100,000 } \\
& & Forcible & \multicolumn{3}{c}{ Aggravated } \\
& Homicide & Rape & Robbery & Assault \\
1960 & 13.7 & 29.8 & 121 & 154 \\
1970 & 24.3 & 35.4 & 186 & 218 \\
Change (1960-70) & $77 \%$ & $19 \%$ & $54 \%$ & $42 \%$ \\
1975 & 25.7 & 36.4 & 198 & 276 \\
Change (1970-75) & $6 \%$ & $3 \%$ & $6 \%$ & $27 \%$ \\
1977 & 22.8 & 38.8 & 166 & 276 \\
Change (1975-77) & $-11 \%$ & $7 \%$ & $-16 \%$ & $0 \%$ \\
\hline
\end{tabular}

Sources: U.S. Dept. of Justice, FBI Uniform Crime Reports, 1960, 1970, 1975 and 1977. 
TABLE E

Total Arrests of Persons Aged 13-20

\begin{tabular}{lrrr}
\hline & $1960^{*}$ & $1970 \dagger$ & $1975 \ddagger$ \\
Homicide & 973 & 3,197 & 4,107 \\
Forcible Rape & 3,088 & 6,421 & 7,972 \\
Robbery & 15,141 & 46,806 & 71,708 \\
Aggravated Assault & 12,341 & 35,384 & 62,002 \\
\hline
\end{tabular}

* Estimated 12,868,000 aged 13-20 in Uniform Crime Reports sample population of $106,348,846$.

† Estimated 22,892,000 aged 13-20 in Uniform Crime Reports sample population of $151,604,000$.

† Estimated 28,186,744 aged 13-20 in Uniform Crime Reports sample population of $179,191,000$.

Source: U.S. Dept. of Justice, FBI Uniform Crime Reports, 1960,1970 , and 1975 .

R E F E R E N C E S

American Broadcasting Company. 1978. "Youth Terror: The View from behind the Gun." Television documentary presented 28 June.

Block, Richard. 1977. Violent Crime: Environment, Interaction and Death. Lexington, Mass.: Lexington Books.

Block, Richard, and Franklin E. Zimring. 1973. "Homicide in Chicago, 1965-1970," Journal of Research in Crime and Delinquency 10:1-12.

Boland, Barbara, and James Q. Wilson. 1978. "Age, Crime and Punishment," Public Interest $51: 22-34$.

Clarke, Stevens H. 1974. "Getting 'em Out of Circulation: Does Incarceration of Juvenile Offenders Reduce Crime?" Journal of Criminal Law and Criminology 65:528-35.

Cohen, Lawrence. 1975. Delinquency Dispositions: An Empirical Analysis of Processing Decisions in Three Juvenile Courts. Albany : Criminal Justice Research Center.

Cook, Phillip J. 1976. "A Strategic Choice Analysis of Robbery." In Sample Surveys of the Victims of Crime, ed. Wesley Skogan. Cambridge, Mass.: Ballinger.

Dodge, Richard W., Harold R. Lentzner, and Frederick Shenk. 1976. "Crime in the United States: A Report on the National Crime Survey." In Sample Surveys of the Victims of Crime, ed. Wesley Skogan. Cambridge, Mass.: Ballinger. 
Eigen, Joel. 1977. "The Borderlands of Juvenile Justice: The Waiver Process in Philadelphia." Ph.D. dissertation, University of Pennsylvania.

Gold, Martin, and David J. Reimer. 1975. "Changing Patterns of Delinquent Behavior among Americans 13 through 16 Years Old: 19671972," Crime and Delinquency Literature $7: 483-517$.

Hamparian, Donna, Richard Schuster, Simon Dinitz, and John Conrad. 1978. The Violent Ferw: A Study of the Dangerous Juvenile Offender. Lexington, Mass.: Lexington Books.

Institute of Judicial Administration and American Bar Association, Juvenile Justice Standards Project. 1977a. Standards Relating to Dispositions. Cambridge, Mass.: Ballinger.

- 1977b. Standards Relating to Juvenile Delinquency and Sanctions. Cambridge, Mass.: Ballinger.

Jensen, Gary F. 1976. "Race, Achievement and Delinquency: A Further Look at Delinquency in a Birth Cohort," American Journal of Sociology 82:379-87.

National Academy of Sciences. 1978. Report of the Panel on Deterrence and Incapacitation. Washington, D.C.: U.S. Government Printing Office.

New York Times. 1978a. "Beyond the Teen-Age Gun." Editorial, 28 June, p. 30.

- 1978b. "Boy, 15, Who Killed 2 and Tried to Kill a Third, is Given 5 Years." 29 June, section 1, p. 1.

- 1978c. "Carey, in Shift, Backs Trial in Adult Court for Some Juveniles." 30 June, section 1, p. 1.

Petersilia, Joan, P. W. Greenwood, and M. M. Lavin. 1977. Criminal Careers of Habitual Felons. Santa Monica, Calif.: RAND Corporation. Polk, Kenneth, Dean Frease, and F. Lynn Richmond. 1974. "Social Class, School Experiences, and Delinquency," Criminology 12:84-96.

President's Commission on Law Enforcement and Administration of Justice. 1967. Task Force Report: Juvenile Delinquency and Youth Crime. Washington, D.C.: U.S. Government Printing Office.

Shannon, Lyle W. Unpublished. "Assessing the Relationship of Adult Criminal Careers to Juvenile Careers." Racine, Wis.

Strasburg, Paul A. 1978. Violent Delinquents: A Report to the Ford Foundation from the Vera Institute of Justice. New York: Monarch.

Time. 1977. "The Youth Crime Plague." 11 July, pp. 18-30.

U.S. Department of Commerce, Bureau of the Census. 1960. Characteristics of the Population: U.S. Summary. Washington, D.C.: U.S. Government Printing Office.

- 1970. Characteristics of the Population: U.S. Summary. Washington, D.C.: U.S. Government Printing Office. 
1975. Current Population Reports, Series P-25, No. 541. Washington, D.C.: U.S. Government Printing Office.

- 1977. Current Population Reports, Series P-25, No. 643. Washington, D.C.: U.S. Government Printing Office.

U.S. Department of Health, Education, and Welfare. 1975. Vital Statistics of the United States, 1973. Rockville, Md.: National Center for Health Statistics.

U.S. Department of Justice, Federal Bureau of Investigation. 1960. Uniform Crime Reports. Washington, D.C.: U.S. Government Printing Office.

- 1970. Uniform Crime Reports. Washington, D.C.: U.S. Government Printing Office.

- 1973. Uniform Crime Reports. Washington, D.C.: U.S. Government Printing Office.

—. 1974. Uniform Crime Reports. Washington, D.C.: U.S. Government Printing Office.

—_. 1975. Uniform Crime Reports. Washington, D.C.: U.S. Government Printing Office.

- 1976. Uniform Crime Reports. Washington, D.C.: U.S. Government Printing Office.

- 1977. Preliminary Annual Release-Uniform Crime Reports. Washington, D.C.: U.S. Government Printing Office.

U.S. Department of Justice, Law Enforcement Assistance Administration. 1974. Crime in Eight American Cities. Washington, D.C.: U.S. Government Printing Office.

U.S. Department of Justice, National Criminal Justice Information and Statistics Service. 1976. Criminal Victimization Surveys in Chicago, Detroit, Los Angeles, New York and Philadelphia. Washington, D.C.: U.S. Government Printing Office.

U.S. Department of Justice, Office of Juvenile Justice and Delinquency Prevention. 1978. The Serious Juvenile Offender: Proceedings of a National Symposium. Washington, D.C.: U.S. Government Printing Office.

Van Dine, Stephen, John Conrad, and Simon Dinitz. 1977. "The Incapacitation of the Chronic Thug." Paper presented at the American Society of Criminology meeting, Atlanta, Georgia, November.

Wolfgang, Marvin E., Robert M. Figlio, and Thorsten Sellin. 1972. Delinquency in a Birth Cohort. Chicago: University of Chicago Press.

Zimring, Franklin E. 1975. Dealing with Youth Crime: National Needs and Federal Priorities. A Policy Report to the Coordinating Council on Juvenile Justice and Delinquency Prevention.

- 1976. "Crime, Demography and Time in Five American Cities." Paper prepared for the Hudson Institute Project on Criminal Justice Futures. 
1978. Confronting Youth Crime: Report of the Twentieth Century Fund Task Force on Sentencing Policy Toward Young Offenders. New York: Holmes and Meier.

Zimring, Franklin E., Joel Eigen, and Sheila O'Malley. 1976. "Punishing Homicide in Philadelphia," University of Chicago Law Review 43: 227-52. 
HeinOnline -- 1 Crime \& Just. 1081979 